\title{
MENSWAARDIGHEID EN MENSLIKE REGTE NA AANLEIDING VAN DIE SKRIF.
}

As ons op christelik-sedelike terrein vra na die waarde of waardigheid van die mens, dan kom ons in die Skrif altyd weer uit by die skeppingsverhaal, soos wat ons dit weergegee vind in die eerste hoofstukke van Genesis.

Die outeur of outeurs begin nie met enige onsekerheid nie oor die vraag of die mens bestaan en of hy nie bestaan nie. Hulle het nie van die onbetwyfelbare denkkrag van die mens uitgegaan nie om dan soos die Cartiaanse filosofie oor te gaan tot die gevolgtrekking, dat die mens, omdat hy kan dink, daarom ook werklik moet bestaan. Nee, hulle was veel meer realisties as dit. Die gelowige mens is die mees realistiese mens, wat daar is. Daar was niks waar die antieke mens so seker van was nie, as van die feit dat hy as mens werklik bestaan.

Maar daar was nog ' $n$ tweede stelling, waarvan hy uitgegaan het en dit was die stelling dat God ook bestaan. Nie in die minste het hy ooit getwyfel aan homself of aan God nie. Daarom begin hy ook nie met die soek na 'n antwoord op die vrae of hy as mens bestaan en of God bestaan nie. Die enigste vraag waar hy hom mee besig hou is die vraag: wat is die verhouding van die mens tot God? Hoe staan en bestaan die mens voor God? Dis hierdie vraag waar die hele Bybel hom mee besig hou, van Genesis tot Openbaring.

Dat die Skrif begin met die skeppingsverhaal, was nie om die nuusgierigheid van die nuusgieriges te bevredig nie, maar om die geloof van die gelowiges te versterk. Daarom begin die Skrif om te verhaal, hoe dat God alles in aansyn geroep het en ten laaste ook die eerste mense-paar geskep het. Niks en niemand is vrug van eeue-lange ontwikkeling nie, maar alles is die eiemagtige daad van die almagtige God. En vir hom, wat nie kan uitgaan nie, van die grondstelling dat daar ' $n$ almagtige, algoeie God bestaan, wat alles deur die krag van sy wil daar gestel het, of kon gestel het, vir hom kan die Skrif geen boodskap bring nie. Hy sal die Bybel ook maar stilletjies opsy skuif en vervang met die mensewoord, die kerklike tradisie of die ydel menslike filosofie.

Vir hom wat wel van hierdie geloof wil uitgaan, word dit in Genesis 
baie duidelik gestel, dat God die heelal daargestel het om vir Hom as 'n tempel diens te doen. Alles moes sy naam grootmaak en verheerlik en in daardie tempel sou die mens as priester van God diens doen en om aan die diens van die wêreld tot verheerliking van God leiding te gee. Die mens sou wees die begeleider by die magtige koor, wat gedurig sou sing: heilig, heilig, heilig is die Here van die Leërskare! Hy sou optree as skakel tussen God en die res van die skepsels en die plaasvervanger van God teenoor die medeskepsels. Dit is wat alles verstaan moet word onder die stelling dat die mens in of na die Beeld van God geskape is. Hy sou die Woord van God hoor, as God met hom spreek, m.a.w. hy sou in voortdurende woordverbinding met God staan. Dit beteken dat sy waarde en waardigheid altyd sou afhang van hierdie verhouding tot God. Hy het geleef en kon alleen leef van die guns van God. Maar daar was 'n voorwaarde: hy moes gehoorsaam wees en bly aan God. Die bande met God, die grond van sy menswaardigheid was dus die bande van gehoorsaamheid aan God.

Daarop kom die sondeval, die verbreek van die bande met God. Die verbond van Gods guns word verruil vir die slawe-verbond met Satan, met die ideaal om in die wêreld te kan leef sonder God. Satan het dit so aan die mens gestel dat dit wel moontlik is en die mens het dit geglo. Die mens het die bande met God verbreek, maar God laat dit nie verbreek nie. Hy stel ' $n$ ander Verbond, die Verbond van die genade. Die mens het die Verbond met God verbreek, maar 'n ander Mens sal kom om dit te herstel. Hy sal die kop van die slang vermorsel d.w.s. al die werk van Satan omvergooi en die bande met God volkome herstel. Dis die belofte aan Eva, wat maak dat die mens in die geloof die Verbond van Gods genade in Christus, aanvaar as redding, as verlossing, So kry die mens sy menswaardigheid terug, maar dit staan in die teken van die geloof in Christus in Wie en deur Wie die Verbond van genade tot stand kom. Nog meer as voorheen hang die mens se menswaardigheid nou af van sy verhouding tot God, nou 'n geloofsverhouding deur Jesus Christus die Middelaar „Gods en der mensen".

So het die wetgewer op Sinai dit ook gesien en na aanleiding daarvan die verhouding vasgestel tussen die mens en God sy Skepper-Heer en tussen die mens en sy medemens, in die dekaloog, die tien gebooie. Hierdie wetgewing met sy vasstelling van die menswaardigheid van die mens daarin, was nie in stryd met die Verbond van genade nie, maar staan in die diens daarvan. Dit was vir die mens 'n tugmiddel, 'n leermeester tot op die tyd dat die genade-Verbond deur Christus werklikheid geword het. Die grond van die wet was die moederbelofte aan Eva, maar sy taak was om die eiesinnige mens te tug, te vermaan en te leer tot op die tyd wat bekend sou wees as die volheid van die tyd, wanneer die verlossing werklikheid geword het en die mag van Satan, deur die betaalde losprys aan die kruis, verbreek sou wees. Maar die wet kon nooit oorbodig wees nie, want hy het altyd heengewys na die Verbond van genade en sal altyd daar heenwys. Dat die wet sy betekenis nooit sou verloor nie, het Christus bevestig met Sy samevatting van die wet as die gebod van liefde tot God en die naaste. 
So het die grondlêers van die volksplanting aan die suidpunt van Afrika dit ook geglo, hulle wat bereid was om alles te verloor behalwe hul geloof in God en hul geloof in Jeusus Christus, volgens die Skrif, onse Bybel, die Woord van God. Dis hierdie geloof wat 'n onbetwisbare stempel gedruk het op hul hele lewensopvatting en wat ook gemaak het dat hulle bereid was om alles tydeliks op te gee in die ou vaderland om hier 'n nuwe vaderland te kom soek. Uit hierdie geloof het hulle 'n eie lewenspatroon ontwikkel en wat hulle altyd as 'n God-gegewe erfenis beskou het en so ook aan hul nageslagte oorgegee het. Dis hierdie lewenspatroon wat die nageslagte nie kan loslaat nie en wat vir die vreemdeling 'n oorsaak tot bittere ergernis is tot vandag nog.

Die vreemdeling het ' $n$ ander agtergrond, 'n ander geloof en kom met 'n ander lewenspatroon. Die diepste grond vir verskille t.o.v. die rassebeleid in Suid-Afrika is daarom nog alty'd gewees 'n verskil van geloof en godsdiens. Vir hom wat nog altyd agter goud en diamante aangetrek het, is dit haas onmoontlik om hom met die Afrikaner se sienswy'se te vereenselwig. Alleen namate die Afrikaner losgemaak kan word van sy oorgeerfde lewensopvatting, wat skriftuurlik gefondeer is, na die mate sal hy sy lewenspatroon ook t.o.v. die verskillende rasse in Suid-Afrika los kan laat en na die mate sal daar minder verskille oorbly tussen sy rassebeleid en die liberalistiese opvattings van die kultuurprotestantisme van die Anglikaanse religieuse filosofie, wat vandag sy stempel druk op die hele Wêreld-raad van Kerke en deur hierdie volslae liberalisties-etiese liggaam op die hele protestantse wêreld van vandag.

Maar ons mag nie negatief wees nie. Dit sal ons niks baat nie om tot ons grootste ergernis ons besig te hou met die kerklike strominge wat die klok van die christelike geloof wel hoor lui het, maar nie weet nie waar die belletjie hang. Daarom keer ons terug na die Suid-Afrikaanse Pionier, die Hollandse Watergeus en die Franse Hugenoot, wie se hele lewensuitsig as calvinis gegrond was in die liggewende krag van die Woord van God in die Skrif. Die Bybel was vir hulle nie maar net 'n etiese referensieboek nie, wat mooi en navolgenswaardige lesse en voorbeelde bevat, veral in so ver as wat sulke lesse in ooreenstemming is met die beste, wat die menslike gees tot sover tevoorskyn gebring het nie. Maar hierdie Boek was vir hom Gods Woord, 'n Lig op die pad en 'n Lamp vir die voet vir hierdie lewe en die lewe daarna. En hy het goed geweet dat as hy hierdie skriftuurlike gefondeerdheid van sy rassebeleid sou prys gee hy daarmee sy hele lewensfondament onder sy voete sal laat uitskop. Dis om hierdie rede dat hy en sy nageslag en geestelike erfgename so dikwels nie verstaan word nie en daarom al vaak uitgemaak is vir "primitive Calvinists”.

In die lewe van hierdie calvinistiese grondlêer van die fondamente van die Boerenasie, het die dekaloog, die tien gebooie, as staande in die diens van Gods Verbond van genade in Christus, 'n plek van haas onbeskryflike betekenis gehad. Dit geld veral die twede deel van die tien gebooie, waar dit gaan oor die houding tot en sy verhouding teenoor die medemens. 
Hier het hy lig gekry vir sy probleme en vrae hoe hy hom moet gedra teenoor die primitiewe rasse, met wie hy hier in aanraking kom. Aan die een kant het gestaan die eis van liefde tot die naaste, al was dit nie juis terwille van hierdie naaste self nie, maar dan tog terwille van God, van wie hierdie naaste ook 'n skepsel is. Aan die ander kant het gestaan die toestand van primitiwiteit en besondere agterlikheid, so anders as wat maar ergens anders in die wêreld sprake van kan wees. Hierdie dilemma het veral bestaan t.o.v. die Boesmans, wat so agterlik en daarby so slu en agterbaks was, dat daar nouliks met hulle 'n verhouding aangeknoop kon word. T.o.v. die Hottentotte was dit ietwat beter gestel. Later het die Koloniste aan die Kaap ook in aanraking gekom met die Bantoes, met wie (hoewel onbeskaafd) daar wel 'n verhouding aangeknoop kon word. Die onderhandelings tussen Piet Retief en Dingaan wys dat die Boere selfs gereken het, dat Dingaan 'n erewoord gehad het, waar hulle op kon reken. En die latere ervarings met die Boesmans het uitgewys dat hulle, nadat hulle „makgemaak" is, tog nie onvatbaar is nie vir die elementêre beginsels van die westerse beskawing. Die feit dat al hierdie gekleurde rasse net in graad van beskawing van die Blankes verskil en dus as medeskepsels na die Beeld van God beskou moet word, het die calvinistiese christen gedwing om 'n ander houding teenoor die inboorlinge aan te neem as teenoor al die ander lewende wesens. Tog is dit waar dat daar Blankes was, wat dit met groot erns betwyfel het dat die primitiefste onder die primitiewes vatbaar kon wees vir die Evangelie en dat daar plek vir hulle in die Hemel kon wees. Maar dit geld die uitsonderings.

Uitgaande van die geloof dus dat hierdie mense ook medeskepsels is en daarom ook kinders van God kan wees, het die blanke christen hoe langer hoe sterker tot die oortuiging gekom, dat hy 'n roeping van God het teenoor die primitiewe inboorlinge van hierdie land, maar watter houding moet hy aanneem teenoor hulle t.o.v. die maatskaplike lewe? Hier is toe die begrip van geskeidenheid en apartheid gebore. Dit was in elk geval beslis onmoontlik gewees om te dink aan 'n gemeenskaplike eenheidsstrewe met hierdie primitiewe groepe. Vir die Blanke christene sou dit beteken het die vernietiging van hul eie kultuur en volk en wat nog erger sou wees, die vernietiging van al wat christelik is. Die menswaardigheid van die mens is vrug van sy verbondenheid met God die Skepper-Heer en hier by hierdie primitiewe volke was nie die minste sprake van 'n godsbegrip nie en daarom is dit, dat die mens hier sy menswaardigheid verloor het, tot so 'n mate, dat daar soms twyfel bestaan het, of hulle ooit weer 'n Godsbesef kon ontwikkel en ooit weer hulle menswaardigheid terug kon vind. Die Kaapse christene het hulle hierin laat lei deur die geskiedenis van Israël ná die ballingskap onder die bestuur van Esra en Nehemia. En net so seker as wat Israël sy roeping sou verloor het, as hy hom sou laat verbrokkel en vernietig het kultureel, nasionaal en godsdienstig deur 'n vermenging met die Samaritane en die ander inwoners van Palestina, net so seker sou hierdie Blanke christene in Suid-Afrika hul roeping ook ver- 
loor het teenoor die gekleurde rasse, as hulle nie met die uiterste kragsinspanning hulleself hier gehandhaaf het nie.

Dat dit hier nooit uitgeloop het nie op die uitdelging van die ander rasse, soos wat elders in die wêreld wel gebeur het, is alleen te danke aan die Blanke nedersetters se geloof aan God as die Skepper-Heer van alle mense na Sy Beeld en Sy Gelykenis en hul geloof dat daar vir hulle 'n van God gegewe roeping is teenoor hierdie minder bevoorregte kinders van God. Dit is aan hierdie geloof te danke dat die Bantoes gegroei en gebloei het en dat die Hottentotte saam met die vrjgelate slawe ontwikkel het tot die kleurlinggemeenskap van vandag. As daar mense vandag in Suid-Afrika is, wat die Here God moet loof en dank, daarvoor dat dit geloofshelde en geloofsheldinne was, wat hier die grondslag kom lê het van die westerse beskawing, met die christelike kerk in Suid-Afrika, dan is dit die Bantoes en die Kleurlinge. Dit kon ook ander westerlinge gewees het. Dit kon dié gewees het, wat alleen soek na die stoflike voordele, sonder om te let op die middels, wat hulle vir hul doel gebruik. Selfs die geskiedenis van Suid-Afrika kan hiervan getuig. En dan kon die geskiedenis van ons gekleurde rasse baie anders gewees het. Die geloof an God en die geloof aan die wet van God en die christelike liefde tot die naaste, het hulle gered en hulle mag dit nie strafloos vergeet nie.

Die dekaloog: jy moet jou naaste lief hê soos jouself, het aan die Blanke christen sy besef van plig teenoor die gekleurde rasse in SuidAfrika gegee en dit het daardie besef, selfs onder die moeilikste omstandighede ook wakker gehou. Maar een-en-dieselfde maatskaplike struktuur kon dit hier nooit word nie. Dit sou selfmoord wees en sonde teen God. Maar dit was ook nie nodig nie en die teenoorgestelde n.l. die uitwissing van hierdie rasse was ook nie nodig nie. Die Woord van God het weer die weg gewys. Vir Irsael was dit al die eeue deur nodig om sy identiteit te bewaar. Was dit onnodig diskriminasie van Moses toe hy Israël ernstig gewaarsku het om nie met die ander rasse te vermeng nie, al sou hulle ook die godsdiens van Israël aanvaar? En Esra en Nehemia, wat die gemengde huwelike verbied het en selfs ongedaan gemaak het, terwille van die volk se roeping teenoor die res van die wêreld, was dit uit selfverheffing gewees of het hulle dit gesien as die ontwyfelbare voorwaarde vir die vervulling van hul lewensroeping? En moet ons die Here God nie dank nie vir hierdie ligtende voorbeelde vir ons eie voorouers? Voorwaar 'n kosbare erfenis, ' $n$ geloofserfenis vir die geslagte van vandag. Dis alleen die toppunt van gebrek aan geloof op hierdie punt, wat hierin kan lei tot 'n veroordeling van die geslagte wat verby is. Dis verraad teenoor die geloofshelde en geloofsheldinne van weleer.

Vermenging van rasse en die ontkenning van die andersheid, wat deur God daargestel is, sou selfmoord beteken het en daarom was die weg, wat deur Gods Woord anngewys word, die enigste moontlike weg, die enigste eerbare en die enigste christelike weg nl. die weg van aparte ontwikkeling, 
die weg van handhawing van die verskeidenheid en geskeidenheid van alle rasse en groepe. Dat die opgee van die geskeidenheid moet uitloop op bloedvermenigng, moet uitloop op die opheffing en vernietiging van die verskeidenheid, kan alleen deur 'n dwaas betwyfel word.

So het die patroon van apartheid of segregasie, die vrye naasmekaarbestaan van alle rasse en groepe in die Suid-Afrikaanse volkerelewe sy beslag gekry. Dis ook nie iets nuuts nie, maar so oud soos die menslike samelewing self. En dat God self dit bewerk het met die spraakverwarring by die toring van Babel, was nie 'n Goddelike straf vir die hoogmoed van die aardbewoners nie, maar ' $n$ openbaring van Gods genade. Die sondige en van God afgedwaalde mens bederf sy lewe keer op keer, maar God herstel altyd weer. $\mathrm{Hy}$ gee genade op genade. Hierdie apartheid is skriftuurlik gegrond en daarom ook christelik, maar dis ook natuurlik en regverdig. Dis natuurlik dat elke mens en elke groep en elke ras alleen dan kan ontwikkel ook tot nut van sy medemens, wanneer hom gegun word om homself te wees en sy verantwoordelikheidsbesef te ontwikkel. En dit is die grootste misdaad teen die menslike geslag om die een of ander ras of volk of groep of indiwidu te hinder in hierdie ontwikkelingsproses en dit is waar elke vorm van verydeling van apartheid op neerkom. Dis ook veral hier in die aparte, selfstandige gemeenskap met sy ontwikkelde verantwoordelikheidsbesef, waar daar 'n oor sal wees vir die Evangelieprediking. Enige nasionale ontwaking vereis ' $n$ aparte selfstandige bestaan vir elke aparte volk, so gou hy instaat is om selfstandig te bestaan. Dit gee hom roepingsbesef en dit maak hom deemoedig wanneer hy begin glo dat hierdie roeping van God kom. Nasionalisme verdiep die lewe, terwyl die internasionalisme en liberalisme dit vervlak. Dis hier waar die menswaardigheid van die mens onder die prediking van Gods Woord, omdat hy nou weer weet dat hy skepsel van God is, langsaam weer kan kan herstel. Dis ook alleen hier waat 'n gesonde nasionale atmosfeer, wat christelik gefondeer is, waar die menseregte van elke indiwidu nog enige waarde het, want hier word die mens gedwing om homself te sien as die hoeder van sy broeder. Die saamverbindende faktor is die besef van volksverbondenheid, wat deur die geloof geregverdig is en deur die geloof instand gehou word. By die materialistiese lewensbeskouings, waar die volksverbondenheid nie enige gewig kan dra nie, word die nasionale vervang met enigiets wat stoflik van oorsprong is. Hier kry mens 'n klasseverdeling, wat lynreg staan teenoor die nasionale godsdienstige, omdat die materialistiese altyd stryd voer teen alles wat geestelik is. Die christelik-nasionale klasseverdeling van die Afrikaner is die mees geestelike en tegelykertyd die mees werklike verdeling van klasse en groepe, wat bekend is. Dis alleen moontlik by die volk wat gedra word en instand gehou word deur sy onverbreekbare besef van volksverbondenheid aan die een kant en sy geloof aan God aan die ander kant. Die kapitalisme en die kommunisme staan altyd vir 'n materialistiese klasseverdeling en het assodanig nie alleen vir nasionalisme geen plek nie, maar vir die christelike geloof ook nie. 
Die teenvoeter van die menswaardigheid van die mens deur sy verbondenheid aan God, is in ons tyd die Westerse Liberalisme en die Oosterse Kommunisme, wat in hierdie tydsgewrig mekaar se hande vasgegryp het. Die eerste verdedig kragtens sy humanistiese uitgangspunt die goddelikheid van hierdie menswaardigheid en deur die laaste word dit geloën. Die eerste lei op sy beste tot ' $n$ verwarde idealisme en die laaste tot die verdierliking van die mens. Die eerste sien die mens as doel in homself, die tweede beskou die mens alleen as middel tot 'n selfsugtige eiesinnige doelstelling. Die menswaardigheid van die mens in sy relasie tot God as dienskneg en diensmaag van die Allerhoogste, het by albei verlore gegaan, omdat die geloof in God en die geloof in die Christus van God verlore gegaan het. Die Liberalisme, soos wat dit sig uitleef in sommige kerklike groepe in Suid-Afrika, in die Wêreldraad van Kerke, in die V.V.O. en in die raadsale van die meeste volke van die westerse wêreld, is die tekens van 'n verarmde mensdom, omdat sy Christendom verarm het. Vir hierdie Christendom wat meer die tekens van die AntiChris vertoon as die van die Christus van God, is dit nie die moeite werd om voor te leef nie, nog minder om voor te sterf.

Wat 'n toestand! Dis die blindes en verblindes wat in ons tyd die weg wil aanwys, nie die wat nog kan sien nie. Dis 'n kranksinnige wêreld waar ons in leef! Sal daar weer 'n beter dag kom? God weet dit. Sal die kerke van die westerse wêreld dan nie weer ontnugter word nie? Geluk$\mathrm{kig}$, die ware gelowiges wat die menswaardigheid van die mens alleen sien in sy verhouding tot God as kind van God, die is daar nog. Alleen, hulle word nie gehoor nie. Hulle roep maar hul stemme word gesmoor. Die dwaasheid van die dwases word luid uitgebasuin, deur die radio en deur die pers en wantroue word gesaai teen alles wat nog christelik is. Maar die Here God slaap nie ook nie.

Dit alles wil nog nie sê nie dat onder ons in die christelike kerk en in ons land, daar nie diesodaniges is nie, wat hierdie menswaardigheid alleen vir homself opeis en vir sy eie groep. Die stryd teen die Liberalisme van die modernistiese groepe in ons land het meegebring, dat hierdie menswaardigheid so dikwels ontsê word aan mense van ander rasse en kleur en dit is 'n gruwel. Diskriminasie in die sin van veragting en verguising van ander minderbevoorregte skepsels van God, is 'n skandvlek op die lewe van die nasaat van die Hollandse Watergeus en die Franse Hugenoot en die Vrystaatse of Transvaalse Voortrekker en is voor God en die christelike gewete nie te verantwoord nie. Dis 'n euwel en openbare sonde wat uitgeroei behoort te word. Die onverantwoordelike optrede van onreformatoriese kerklike groepe en indiwidue, wat vermenging en die uitwissing van 'n natuurlike verskeidenheid voorstaan, kan en mag geen regverdiging word nie, vir 'n houding wat in stryd is met die Skrif en die christelike gewete in die algemeen. Om hierdie euwel te bestry, daarvoor is nodig 'n aparte ontwikkeling, in 'n aparte eie tuiste vir elke ras of volk of groep, omdat die verskille van ras of kleur natuurlike 
verskille is en omdat 'n huis, wat uit sulke verskillende elemente bestaan, teen homself verdeel is en daarom ook nie kan bestaan nie. Om hierdie euwel van diskriminasie te bestry is absoluut noodsaaklik. Dit staan nie in die diens van die ideaal van afsonderlike naasbestaan nie, maar sal apartheid en alles waarvoor dit wil staan, laat misluk. Hierdie regverdige en natuurlike naasmekaarbestaan, is wat mens positiewe apartheid kan noem. Negatiewe apartheid daarteenoor het twee vorms. Dit bestaan aan die een kant in die onchristelike diskriminasie en verguising van wie met my verskil in ras of volk of kleur en op grond daarvan 'n absolute skeiding eis. Of dit bestaan aan die ander kant in 'n meer verfynde vorm van diskriminasie onder die dekmantel van allerlei mooi terms, soos integrasie, vennootskap, ens. om so die mens dan tog in dieselfde maatskaplike struktuur vir eie doeleindes te gebruik, maar homself tog altyd as die beheersende faktor te handhaaf. Die een is so onnatuurlik, so onregverdig en so onchristelike as die ander.

Die positiewe en christelike apartheid gaan uit van die deur God daargestelde verskeidenheid, van die menswaardigheid van elke mens as skepsel van God, wat hom ontplooi in die mens se verhouding tot God, as sy Skepper-Heer en juis daarom gaan dit ook uit van die dekaloog. Jy moet jou naaste liefhê soos jouself.

Dat die Kommunisme hierdie positiewe apartheid verwerp, kom deur sy anti-godsdienstige en anti-christelike uitgangspunt. Die Kommunisme is immers gebore uit die haat teen die christelike geloof. $\mathrm{Hy}$ kan nie anders nie as om 'n stryd te voer van lewe op dood teen alles wat christelik van oorsprong is. En die Liberalisme van die westerse wêreld van vandag se stryd teen hierdie positiewe apartheid, kom omdat hy die inhoud van die christelike geloof verloor het en hom daarom ook nie kan skaam nie daarvoor dat hy met sy dwase stryd vir 'n dwase liberalisme die pad vir die Kommunisme baan. Dit gebeur in Suid-Afrika, Midde Afrika, die hele Afrika. Wat 'n tragedie!

H. P. Wolmarans. 